\title{
JIHAD SUFI
}

\section{Muhammad Amin Sahib}

\begin{abstract}
This paper explores what the meaning of jihad and Sufi is and how a Sufi jihad. The aim of this research is to correct the wrong understanding of Sufism and Sufi teachings and explain that Sufism in Sufism never lags in jihad with its various aspects. Jihad is all forms of maximum effort for the application of Islamic teachings and eradication of tyranny, both for oneself, society and the universe by not knowing despair, surrender, and strings attached, both through physical struggle, emotions, possessions, energy, and science in order reach the pleasure of Allah Almighty. Being Sufi is a person who tries to purify and decorate himself with commendable qualities to draw closer to Allah. Sufis not only adorn themselves with praiseworthy qualities and mahdhah worship rites only to God Almighty, but a Sufi person is still required to draw closer to Allah swt with jihad efforts such as spiritual jihad, ethical jihad, intellectual jihad and politics.
\end{abstract}

Keyword: Islam; Jihad; Sufi

\begin{abstract}
Abstrak
Tulisan ini mengetengahkan apa makna jihad dan sufi dan bagaimana seorang sufi berjihad. Tejuan penelitian ini adalah akan meluruskan pemahaman yang salah terhadap ajaran tasawwuf dan sufi serta menjelaskan bahwa sufi dalam tasawwufnya tidak pernah ketinggalan dalam jihad dengan berbagai aspeknya. Jihad adalah segala bentuk usaha maksimal untuk penerapan ajaran Islam dan pemberantasan kezaliman, baik untuk diri sendiri, masyarakat dan alam semesta dengan tidak kenal putus asa, menyerah, dan pamrih, baik melalui perjuangan fisik, emosi, harta benda, tenaga, maupun ilmu pengetahuan demi mencapai ridha Allah swt. Sedang sufi ialah orang yang berusaha mensucikan dan menghiasi dirinya dengan sifat-sifat terpuji untuk mendekatkan diri kepada Allah swt. Sufi tidak hanya menghiasi dirinya dengan sifat-sifat terpuji dan ritul ibadah mahdhah semata kepada Allah swt, tetapi seorang sufi tetap dituntut mendekatkan diri kepada Allah swt dengan usaha jihad seperti jihad spiritual, jihad etik, jihad inteletual dan politik.
\end{abstract}

Kata Kunci: Islam; Jihad; Sufi

\section{PENDAHULUAN}

Tasawuf biasa juga disebut dengan mistisisme Islam. Orientalis Barat menyebutnya sufisme dan mengkhususkan pemakaian kata sufisme untuk 
mistisisme Islam. Nama sufisme tidak dipakai untuk mistisisme-mistisisme yang terdapat dalam agama lain (Nasution, 1978: 56)

Sufisme atau tasawwuf adalah suatu cabang ilmu pengetahuan dan sebagai ilmu pengetahuan, tasawwuf mempelajari cara dan jalan bagaimana seorang dapat mendekatkan diri sedekat mungkin dengan Allah swt. Orang yang bertasawwuf disebut sufi. Banyak cara atau jalan yang harus ditempuh oleh seorang sufi dalam mendekatkan diri kepada Tuhan yang lazim sebut dengan maqāmāt dan ahwāl. Para sufi pada dasarnya lebih banyak sepakat dalam menetapkan maqāmāt dan ahwāl, namun ada juga perbedaan di antara mereka termasuk dalam hal pencapaian kedekatan atau bahkan persatuannya dengan Tuhan. Sebagian menilai bahwa mereka sufi adalah kafir, dengan alasan karena di antara mereka ada yang mengaku bersatu dengan Tuhan atau Tuhan bersatu dengan mereka dengan berbagai teori dan istilah seperti al-ittihād, al-hulūl dan wahdah al-wujūd.

Di sisi lain, tasawwuf dalam sejarahnya terombang-ambing oleh berbagai tudingan yang mengatakan bahwa tasawwuf dengan ajaran zuhudnya dapat membawa kepada kevakuman pemikiran dan kemorosotan umat Islam. Bahkan belakangan keberadaan tasawwuf pun dipertanyakan, apakah tasawwuf harus dibuang karena tidak lagi sesuai dengan modernisasi dan perkembangan ilmu pengetahuan dan zaman? atau apakah tasawwuf tetap harus dipelajari dan dipertahankan karena dengan tasawwuf justru bisa membawa manusia kepada ketenangan jiwa dalam menghadapi problematika kehidupan dan perkembangan zaman.

Tulisan ini akan meluruskan pemahaman yang salah terhadap ajaran tasawwuf dan sufi serta menjelaskan bahwa sufi dalam tasawwufnya tidak pernah ketinggalan dalam jihad dengan berbagai aspeknya.

\section{SUFI DAN JIHAD}

\section{Sufi dan Tasawwuf}

Berbagai pendapat muncul mengenai asal-usul istilah sufi dan Tasawuf Para ulama muslim terdahulu berpendapat bahwa kata itu berasal dari ahlu al-suffah 
(orang yang menyempurnakan batin dan jiwa yang tinggal di masjid Nabi). Beberapa ulama lain menyebutkan dari kata sāf artinya jajaran atau tingkat, karena kaum sufi menduduki tingkatan kesatu. Ulama lain condong kepada kata safā (kesucian). Sedang pendapat yang terakhir mengatakan sufi berasal dari kata sūf artinya bulu domba. Sementara para sarjana Barat berusaha menghubungan kata sufi dengan kata sophis dari sophos (Nadvi, 1984: 73).

Pendapat terakhir, penulis kurang sependapat karena terlalu jauh dari kata Tasawuf Penulis lebih cenderung kepada pendapat yang mengatakan bahwa kata tasawwuf berasal dari sūf. Orang yang berpakaian bulu domba disebut mutasawwif, sedang prilakunya disebut Tasawuf Ini pada lahirianya, sedang pada esensinya lebih cocok kepada safā karena kebersihan hati dan jiwa para pelakunya. Telah disebutkan juga oleh Muhammad Fauqī (1)ajāj bahwa sebagian besar ahli sejarah tasawwuf cenderung kepada pernyataan bahwa isytiqāq kata tasawwuf dari sūf dan pe-nisbah-an sufi kepada sūf. Pendapat mereka ini, menurutnya sesuai dengan kaidah bahasa (Fauqī Hajāj, 1992: 20).

Memberikan suatu defenisi tentang tasawwuf adalah pekerjaan yang sulit karena umumnya defenisi yang dikemukakan para sufi adalah hasil pengalaman batin mereka dalam melakukan hubungan dengan Tuhan. Dari sekian banyak defenisi, Zakariyā al-'Ansārī berusaha meringkasnya bahwa tasawwuf mengajarkan cara untuk menyucikan diri, meningkatkan akhlak, dan membangun kehidupan jasmani dan rohani untuk mencapai kebahagiaan abadi. Unsur utama tasawwuf adalah penyucian diri dan tujuan akhirnya kebahagiaan dan keselamatan abadi (Dewan Redaksi Ensiklopedi Islam 5, 1994: 74).

Dari paparan di atas, dipahami bahwa Tasawwuf ialah ajaran atau cara mendekatkan diri kepada Allah swt dengan menghiasi diri dengan sifat-sifat terpuji. Sedangkan sufi ialah orang yang berusaha mensucikan dan menghiasi dirinya dengan sifat-sifat terpuji untuk mendekatkan diri kepada Allah swt.Adapun tentang asal usul ajaran tasawwuf, para sarjana, baik dari kalangan orientalis maupun dari kalangan Islam sendiri berbeda pendapat tentang faktor 
yang mempengaruhi munculnya tasawwuf dalam Islam.

Harun Nasution menyebutkan bahwa asal timbulnya tasawwuf antara lain: Pertama, pengaruh kristen dengan paham menjauhi dunia dan mengasingkan diri dalam biara-biara. Dikatakan bahwa zāhid dan sufi meninggalkan dunia, memilih hidup sederhana dan mengasingkan diri adalah atas pengaruh cara hidup para rāhib Kristen ini. Kedua, falsafat mistik Pythagoras yang berpendapat bahwa roh manusia bersifat kekal dan berada di dunia sebagai orang asing. Badan jasmani merupakan penjara bagi roh. Kesenangan roh yang sebenarnya ialah di alam samawī, maka manusia harus membersihkan roh dengan meninggalkan hidup materi (zuhd), untuk selanjutnya berkontemplasi. Inilah menurut sebagian orang, yang memengaruhi timbulnya zuhd dalam Islam. Ketiga, Falsafat emanasi Plotinus yang mengatakan bahwa wujud ini memancar dari zat Tuhan yang maha esa. Roh berasal dari Tuhan dan akan kembali kepada Tuhan. Tetapi dengan masuknya ke alam materi, roh menjadi kotor, dan untuk kembali ke asalnya roh harus terlebih dahulu dibersihkan. Pensucian roh yaitu dengan meninggalkan dunia dan mendekati Tuhan sedekat mungkin, kalau bisa bersatu dengannya. Dikatakan pula ini mempunyai pengaruh terhadap munculnya kaum zāhid dan sufi dalam Islam. Keempat, ajaran Budha dengan paham nirwananya. Untuk mencapai nirwana, orang harus meninggalkan dunia dan memasuki hidup kontemplasi. Paham fanā' dalam sufisme Islam hampir serupa dengan paham ini. Kelima, ajaran-ajaran Hinduisme yang juga mendorong manusia untuk meninggalkan kematerian dunia dan mendekati Tuhan untuk mencapai persatuan Atman dengan Brahman (Nasution, 1978: 58-59).

Lanjut Harun Nasution, benar atau tidaknya teori ini susah dibuktikan. Tetapi bagaimanapun, dengan atau tanpa pengaruh-pengaruh dari luar, sufisme bisa timbul dalam Islam sendiri karena ada ayat-ayat Alquran yang dapat dijadikan dasar (Nasution, 1978: 59).

Terlepas ada tidaknya ayat-ayat Alquran yang dijadikan dasar, penulis berkeyakinan bahwa prinsip ajaran tasawwuf memang sudah ada jauh sebelum 
Nabi Muhammad diutus, dengan alasan bahwa: Pertama, ajaran Tuhan untuk manusia sudah ada sejak manusia pertama. Kedua, kitab-kitab wahyu Tuhan dan ajaran nabi-nabi-Nya, seperti Kitab Zabur, Taurat dan Kitab Injil, tentu berisikan sesuatu yang kurang-lebih "sama" dengan Alquran dalam hal perintah dan cara mendekatkan diri kepada Tuhan. Ketiga. Nabi Muhammad sebelum diangkat menjadi Nabi dan Rasul juga melakukan proses meditasi/tahannus yang kemungkinan besar dilihat dari ajaran sebelumnya, karena Nabi saw. belum menerima wahyu. Jika demikian, maka tidak perlu berapologi bahwa tasawwuf atau sufisme lahir dalam Islam itu sendiri, walaupun mistisme Islam sedikit berbeda dengan mistisisme di luar Islam dalam beberapa hal. Perbedaan antara sufisme/mistisisme Islam dan bentuk mistisisme lain di antaranya ialah sufisme dalam usahanya mensucikan jiwa tidak melalaikan kebutuhan jasmaninya, sedangkan mistisisme lain tidak menghiraukan aspek jasmani kehidupan manusia dan mencurahkan pada perbaikan jiwa semata (Nadvi, 1984: 100).

Secara teori, tasawwuf/mistisisme Islam baru menampakkan bentuknya pada masa Rasulullah saw., yaitu ketika beliau memulai tahannus di Gua Hira hingga mendapatkan jawabannya. Kehidupan keseharian Nabi selanjutnya, baik berupa ibadah, akhlak dan muamalahnya. Kemudian diikuti oleh sahabat-sahabat beliau sampai masa Khulafā' al-Rāsyidūn, termasuk kaum Muhajirin fakir yang tinggal diserambi masjid yang dikenal sebagai ahlu al-suffah. Semua kehidupan mereka yang berkaitan dengan keteguhan iman, ketaqwaan, kezuhudan, dan budi pekerti luhur dijadikan sebagai acuan bagi para sufi.

Disebutkan oleh Harun Nasution, bahwa yang mula-mula muncul adalah zuhhād. Zāhid pertama yang dan termasyhur adalah al-Hasan al-Basrī (642-728 M), ia dipandang oleh kaum sufi sebagai imam mereka. Ia melihat dunia ini sebagai ular yang halus dalam pegangan tangan tetapi racunnya membawa kepada maut oleh sebab itu ia menganjurkan supaya orang menjauhi hidup keduniaan. Ia pernah mengatakan: "aku zāhid terhadap dunia ini karena ingin dan rindu pada akhirat" (Harun Nasution II, 1986: 74-75). 
Zāhid lain yang juga besar pengaruhnya bagi kaum sufi ialah Ibrāhīm bin Adham anak seorang raja dari Balkh di Khurasān yang lahir di Makkah ketika orang tuanya berhaji. Satu riwayat menyebutkan, suatu ketika dia bermimpi mendengar ada orang berjalan di atas genteng istananya. Ketika ia bertanya, orang itu menjawab: "aku orang yang engkau kenal, ontaku hilang dan aku sedang mencarinya." Bertanya Ibrāhīm: "Bagaimana engkau dapat mencari onta yang hilang di atas atap istana?". Ujar orang itu: "Hai Ibn Adham, bagaimana engkau dapat mencari Tuhan dalam istana raja?" Mendengar suara itu, Ibrāhīm meninggalkan istana dan selanjutnya hidup sebagai zāhid (Nasution II, 1986: 75).

Berikutnya Rābi'ah al-'Adawiah (714-801 M) lahir dan wafat di Basrah, juga seorang zāhidah yang terkenal dengan paham mahabbah-nya. Abū Nasr Bisyr al-1) āfĩ juga zāhid yang tidak memakai sepatu sehingga ia diberi gelar alHāfì (yang tidak beralas kaki). Kemudian pengalaman para sufi semakin meningkat, Żunnūn al-Misri (796-860 M) dengan paham al-ma 'rifah. Al-Gazālī (1058-1111 M) juga dengan paham al-ma'rifah dan atas pengaruh al-Gazālī, tasawwuf dapat diterima oleh Ahlu al-Sunnah dan Jamā'ah. Abū Yazīd alBustāmī (874-947 M) lahir di Persia dengan paham al-ittihād. Husain Ibn Mansūr al-1)allāj yang lahir di al-Madīnah al-Baidā' di Iran Selatan tahun 859 M dan terkenal dengan paham al-hulūl. Kemudian paham persatuan dalam bentuk wahdah al-wujūd dibawa oleh Muhy al-Dīn Ibn 'Arabī (1165-1240 M) yang lahir di Murcia Spanyol. Ibn al-Farīd (1181-1235 M) dari Kairo menimbulkan paham al-haqīqah al-muhammadiah. 'Abd al-Karīm al-Jīlī (w. 1428 M) membawa falsafat al-insān al-kāmil. Jalāl al-Dīn al-Rūmī (w. 1273 M) terkenal dengan cinta sufi kepada Tuhan.

\section{Makna Jihad}

Secara bahasa, kata jihad terambil dari kata "jahd" yang berarti "letih/sukar", karena jihad memang sulit dan menyebabkan keletihan. Ada juga yang berpendapat kata jihad berasal dari kata "juhd” yang berarti "kemampuan", karena jihad menuntut kemampuan dan harus dilakukan sebesar kemampuan 
(Shihab, 1997: 501).

Dalam hukum Islam, jihad adalah segala bentuk usaha maksimal untuk penerapan ajaran Islam dan pemberantasan kezaliman, baik terhadap diri sendiri maupun masyarakat dengan tujuan mencapai rida Allah swt.

Dalam pengertian luas, jihad mencakup seluruh ibadah yang bersifat lahir dan batin dan cara mencapai tujuan yang tidak kenal putus asa, menyerah, kelesuan, dan pamrih, baik melalui perjuangan fisik, emosi, harta benda, tenaga, maupun ilmu pengetahuan sebagaimana yang dicontohkan oleh Nabi Muhammad saw. selama peroide Mekah dan Madinah. Selain jihad dalam pengertian umum, ada pengertian khusus mengenai jihad, yaitu memerangi kaum kafir untuk menegakkan Islam dan makna inilah yang sering dipakai oleh sebagian umat Islam dalam memahami jihad.

Kesalahan memahami jihad yang hanya dimaknai semata-mata perjuangan fisik disebabkan oleh tiga hal. Pertama, pengertian jihad secara khusus banyak dibahas dalam kitab-kitab fiqih klasik senantiasa dikaitkan dengan peperangan, pertempuran, dan ekspedisi militer. Hal ini membuat kesan, ketika kaum Muslim membaca kitab fiqih klasik, jihad hanya semata-mata bermakna perang atau perjuangan fisik, tidak lebih dari itu. Kedua, kata jihad dalam Alquran muncul pada saat-saat perjuangan fisik/perang selama periode Madinah, di tengah berkecamuknya peperangan kaum Muslim membela keberlangsungan hidupnya dari serangan kaum Quraisy dan sekutu-sekutunya. Hal ini menorehkan pemahaman bahwa jihad sangat terkait dengan perang. Ketiga, terjemahan yang kurang tepat terhadap kata anfus dalam Surah al-Anfal/8: 72 yang berbunyi:

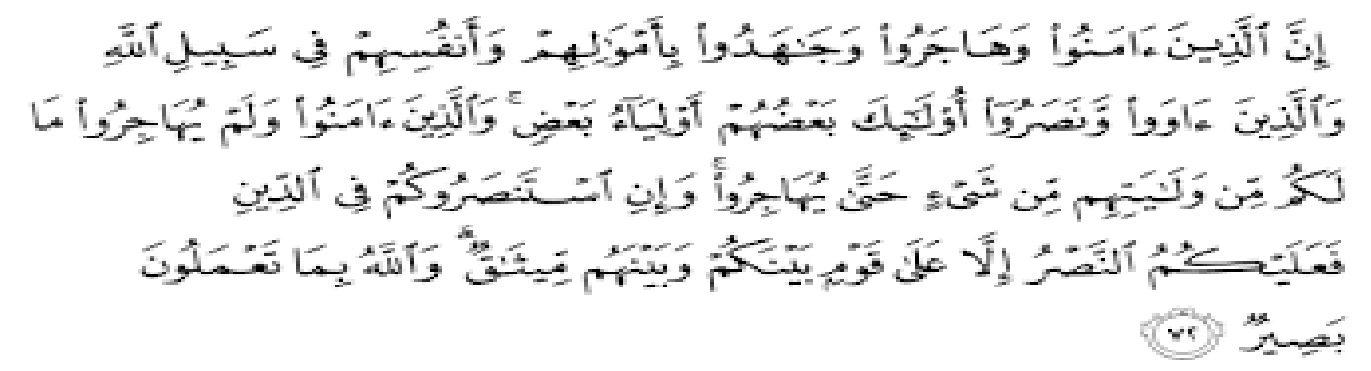

Jihad Sufi

Muhammad Amin Sahib 
"Sesungguhnya orang-orang yang beriman dan berhijrah serta berjihad dengan harta dan jiwanya pada jalan Allah ..."

Kata anfus yang diterjemahkan dengan "jiwa", menurut Quraish Shihab tidak tepat dalam konteks jihad. Makna yang tepat dari kata anfus dalam konteks jihad adalah totalitas manusia, sehingga kata nafs (kata tunggal dari anfus) mencakup nyawa, emosi, pengetahuan, tenaga, dan pikiran.

Kesalahan yang sama juga dialami oleh para pengamat Barat yang sering mengidentikkan jihad dengan holy war atau perang suci. Jihad yang didefinisikan sebagai perang melawan orang kafir tidak berarti sebagai perang yang dilancarkan semata-mata karena motif agama. Secara historis, jihad lebih sering dilakukan atas dasar politik, seperti perluasan wilayah Islam atau pembelaan diri kaum Muslim terhadap serangan dari luar. Oleh sebab itu, holy war adalah terjemahan keliru dari jihad. Holy war dalam tradisi Kristen bertujuan mengkristenkan orang yang belum memeluk agama Kristen, sedangkan dalam Islam jihad tidak pernah bertujuan mengislamkan orang non-Islam.

\section{JIHAD SUFI}

Mengenai jihad sufi, belakangan ini muncul anggapan sekelompok orang terhadap Imam al-Ghazali rahimahullah dalam kaitannya dengan peran beliau saat penyerbuan kaum Salib atas kota al-Quds. Kemudian mengutip ajaran tasawwuf secara sepotong-potong, mereka mencelah para pengamal tasawwuf sebagai kelompok yang lemah dan 'alergi' jihad. Tudingan kepada kalangan tasawwuf tentu saja jauh dari kebenaran. Kenyataan sejarah menyalahkan hal tersebut. Demikian pula, upaya untuk memelintir pandangan dengan menganggap jihad menurut ajaran tasawwuf adalah berbeda dengan ajaran Islam, akan selalu gagal, karena tasawwuf tak terpisahkan dan berakar dari ajaran di dalam Islam itu sendiri.

Hujjatul Islām Imam al-Ghazali sebagai disebutkan KH. Afif Muhammad 
(http:// krapyak.org/2013/02/02/tasawwuf-jihadi/), bukan hanya menulis kitab Ihya' Ulumiddin saja. Sebagai faqih mujtahid, beliau menulis al-Basith, alWasith, dan al-Wajiz, dalam disiplin Fiqh, yang tentu membahas mengenai jihad di dalamnya. Justru dengan Kitab Ihya'nya, Imam al-Ghazali menanamkan mental-mental yang nantinya mampu menghadapi beragam krisis di masa-masa genting sejarah Islam (Baghdad diserang Tartar, al-Quds diserbu kaum Salib). Hasilnya, Dinasti Ayyubi, melalui Syeikh Abdul Qadir al-Jailani merupakan 'anak ideologis' Imam Ghazali. Di Barat (Magrib dan Spanyol), Dinasti Muwahhidun merupakan penjunjung ajaran Imam al-Ghazali diteruskan hingga Imam Syadziliy di Mesir dengan hizib-hizib beliau dalam perang melawan orang Eropa saat itu. Dunia Islam Timur dan Barat sangat dipengaruhi pandanganpandangan Imam al-Ghazali dan jelas sejarah perjuangan ummat Islam dalam jihad selalu dipenuhi dengan peran para pengamal tasawwuf, Tak terkecuali di tanah air. Pangeran Diponegoro dikenal tapabrata (riyādhah), begitu juga Syekh Yusuf yang gigih berjuang melawan penjajah. Demikian pula para pejuang yang lain hampir selalu diketahui terkoneksi dengan pengamal tarekat Tasawuf.

Tentu saja garis waktu peradaban muslim tidak dipenuhi dengan pertempuran saja. Ini karena maqāsid dan tujuan Islam menyatakan bahwa hidup manusia adalah untuk menyembah Allah dan 'imāratul ardl, memakmurkan bumi. Karenanya, peradaban muslim sama sekali tidak mengidealkan kondisi perang terus menerus. Yang pokok dan menjadi tujuan kehidupan adalah bukan perang, melainkan kondisi aman dan damai. Perang merupakan kondisi far'u (cabang), non rutin, yang dijalani jika memang ketentuan Syara' dan serangkaian pertimbangan dzahir dan bathin menghendaki.

Jihad merupakan amalan berupa perlawanan terhadap musuh yang dilakukan demi meninggikan kalimat Allah. Ini adalah pandangan Islam dan tak terkecuali perspektif tasawwuf di dalamnya. Jihad dalam pandangan Islam sendiri memiliki berbagai macam bentuk, dan artikulasi. Kalaupun yang kemudian dikaprahkan bahwa jihad sebagai perjuangan fisik melawan kaum kafir, ini tidak 
menafikan adanya jihad dalam bentuk lain, seperti jihad dengan kata-kata, dengan tulisan, dan justru yang terbesar adalah jihad melawan hawa nafsu. Di sinilah kuncinya, karena tasawwuf merupakan disiplin ilmu yang terejawantah dari aspek ihsan dalam ajaran Islam dan berhubungan dengan membangun jiwa manusia, maka sudah barang pasti jihādunnafs lebih ditekankan dalam Tasawuf.

Jihad meniscayakan adanya musuh. Dalam Islam diajarkan bahwa musuh yang 'paling memusuhi' adalah hawa nafsu yang berupaya menghinggapi dan menguasai setiap diri manusia, apapun kedudukan dan keadaannya. Hawa nafsu selalu berupaya membelokkan manusia dari kebenaran, menjerumuskan manusia dalam kerendahan. Bila nafsu menguasai diri manusia, saat itu pula kesejatian manusia sebagai entitas yang mengusung Kalimatullah runtuh. Karena bersifat batin di dalam diri manusia, dan tidak seperti musuh yang kasat mata, serta muncul setiap saat secara laten maka perlawanan terhadap nafsu tersebut oleh Rasulullah disebut dengan sebagai jihad akbar, jihad besar. Besarnya jihad bukan karena gebyar dan heroik seperti layaknya peperangan, tapi justru karena tak kasat mata, rutin, dan terus-terusan. Perjuangan mempertahankan kesejatian kemanusian inilah yang selalu diingatkan oleh Rasulullah dalam berbagai hadis, baik dengan terma jihad.

\section{Jihad Spiritual}

Persoalan besar yang muncul di tengah-tengah umat manusia sekarang ini adalah krisis spiritualitas. Kemajuan ilmu pengetahuan dan teknologi, dominasi rasionalisme, empirisisme, dan positivisme ternyata membawa manusia kepada kehidupan modern di mana sekularisme menjadi mentalitas zaman dan karena itu spiritualisme menjadi suatu anatema bagi kehidupan modern. Sayyid Hosein Nasr menyayangkan lahirnya keadaan ini sebagai the plight of modern men, nestapa orang-orang modern (Nasr, 1985: 87). Keadaan ini merupakan kelanjutan dari apa yang telah berkembang di Eropa pada akhir abad pertengahan sebagai reaksi terhadap zaman sebelumnya di mana doktrin agama (Nasrani) yang dirumuskan oleh gereja mendominasi semua aspek kehidupan, sehingga mengakibatkan 
bangsa Barat tetap berada pada zaman kegelapan. Lahirnya zaman modern di Eropa serta merta masuk ke dunia Islam, dan begitu kuatnya pengaruh itu sehingga krisis yang sama juga hampir dialami oleh beberapa bagian dunia Islam yang memilih strategi pembangunan sekuler dan karena itu menjauhkan semangat agama dari proses modernisasi.

Sekalipun krisis spiritualitas menjadi ciri peradaban modern, dan modernitas itu telah memasuki dunia Islam, masyarakat Islam tetap menyimpan potensi untuk menghindari krisis itu. Sebabnya ialah sebagian besar dunia Islam belum berada pada tahap perkembangan kemajuan negara-negara Barat. Keadaan ini sangat menguntungkan karena memiliki kesempatan untuk belajar dari pengalaman mereka dan membangun strategi pembangunan yang mampu mengambil aspekaspek positif dari peradaban Barat dan sekaligus menghilangkan aspek-aspek negatifnya. Hal ini bisa dilakukan dengan mempertahankan dasar-dasar spiritualisme Islam agar tetap terjaga kehidupan yang seimbang (Syafiq A. Mughni, http://kawulagusti. blogspot.com/2007/01/ paradigma-tasawwuf-masadepan-islam.html (15).

Beberapa penelitian menyimpulkan bahwa dalam beberapa dekade terakhir spiritualisme dan sufisme mengalami kebangkitan di dunia muslim. Menurut Husain Nasr, sebagian kebangkitan itu berkaitan dengan meningkatnya kegiatan tarekat-tarekat sufi, semacam tarekat Syaziliah atau Ni'matullah yang sangat aktif, seperti di Syiria dan Iran. Lebih dari itu, juga terdapat usaha-usaha serius untuk menggali kembali pemikiran tokoh-tokoh sufi, khususnya Ibn 'Arabī dan mengaktualkannya guna menjawab tantangan-tantangan kemanusiaan dan kerohanian di masa modern (H.M. Amin Syukur, 2002: 127).

Di Indonesia sendiri dalam beberapa tahun terakhir, gejala munculnya tasawwuf ke panggung kehidupan keagamaan juga terlihat jelas. Meskipun penelitian ilmiah belum pernah dilakukan, tetapi media massa sering menginfornasikan. Literatur-literatur dan buku-buku tasawwuf termasuk laku dipasaran. 
Kebangkitan tasawwuf telah menimbulkan banyak pertannyaan khususnya di kalangan pengkaji sosiologi agama dan modernisasi. Mengapa dalam situasi di mana kemajuan ilmu dan teknologi yang kian marak, justru semakin banyak orang tertarik pada tasawwuf? Kesimpulan singkat yang diberikan oleh Naisbitt dan Aburden agaknya menarik. Menurut mereka ilmu pengetahuan dan teknologi yang melaju cepat di era modern tidak memberikan makna kehidupan (Syukur, 2002: 128).

Orang-orang terutama di wilayah urban, merasakan bahwa kehidupan di sekitar mereka semakin keras, sulit dan penuh dengan kriminalitas seolah-olah lepas kontrol. Semula banyak orang terpukau dengan modernisasi, mereka menyangka bahwa modernisasi dengan serta merta akan membawa kesejahteraan. Mereka lupa bahwa di balik itu semua ada gejala yang dinamakan the agony of modernization, azab sengsara karena modernisasi. Gejala itu dapat dilihat, seperti meningkatnya kriminalitas yang disertai tindak kekerasan, kenakalan remaja, gangguan jiwa dan lain sebagainya. Dikemukakan oleh para ahli bahwa gejala psikososial seperti itu disebabkan karena semakin modern suatu masyarakat semakin betambah intensitas dan eksistensitas dari berbagai disorganisasi dan disintegrasi sosial di masyarakat (Hawari, 1995: 129).

Demikianlah, modernisme dipandang gagal memberikan kehidupan yang lebih bermakna kepada manusia. Maka tidak heran jika kemudian orang kembali kepada agama yang memang berfungsi antara lain untuk memberikan makna dan arah dari tujuan hidup. Modernisme dan modernisasi telah gagal menyingkirkan agama dari kehidupan masyarakat. Yang terjadi hanyalah munculnya tantangantantangan baru terhadap agama, tetapi sama sekali tidak melumpuhkannya.

Naisbitt dan Aburdene berpendapat bahwa yang mengalami kebangkitan dalam masa abad agama ini adalah spiritualitas bukan organized religion (Syukur, 2002: 131). Penilaian ini boleh jadi ada benarnya dalam hubungannya dengan agama-agama selain Islam, seperti aliran deisme. Mereka yang beraliran deisme ini bahkan berpandangan bahwa agama-agama formal tidak memiliki masa depan. 
Menurut mereka, yang bertahan hanyalah pesan-pesannya yang universal, namun ritus-ritus formal dan label-label yang membungkusnya akan semakin ditinggalkan orang.

Dalam kasus Islam, seperti disebutkan Azyumardi Azra, kebangiktan nonorganized religion bisa dimaknai dengan fenomena bangkitnya tasawwuf di masa kontemporer ini. Tetapi kebangkitan sufisme bukan satu-satunya yang muncul pada masa pasca modernisme ini. Sisi lain respon Islam adalah yang disebut sebagai fundamentalisme. Fundamentalisme yang dimaksud adalah suatu paham untuk membangkitkan kembali Islam kepada doktrin-doktrin murni Islam seperti masa klasik dalam sejarah Islam, di mana praktek-praktek kaum muslim dipandang lebih islami (Syukur, 2002: 132).

Seperti sufisme, kemunculan fundamentalisme Islam juga terlihat di manamana. Persoalan kemudian, mampukah fundamentalisme menjawab gejala dan perkembangan masyarakat sementara ia berpijak pada sikap literal yang kaku. Perkembangan masyarakat pasca modern tidak memadai lagi untuk dipenuhi dengan sekedar literalisme doktriner dengan ibadah-ibadah pokok saja. Tetapi orang lebih memerlukan pengalaman keagamaan lebih intens dalam proses pencarian makna. Jawaban ini hanya diberikan oleh sufisme.

Jawabannya ialah kembali kepada sufisme, lebih tepatnya neo-sufisme yang menjuruskan aktifisme dan menanamkan kembali sikap positif kepada dunia. Tidak hanya menekankan pentingnya aktifisme intelektual, tetapi juga menekankan pentingnya aktifisme dalam bentuk-bentuk yang lebih praktis.

\section{Jihad Etik}

Sebagai akibat modernisasi dan industrialisasi, kadang manusia mengalami kepincangan moral yang dapat menjatuhkan harkat dan martabatnya. Kehidupan modern sekarang ini sering menampilkan sifat-sifat yang kurang dan tidak terpuji, seperti hirs, hasūd, riy $\bar{a}$ ' dan lainnya. Untuk menghilangkannya, dapat dilakukan dengan mengadakan penghayatan atas iman dan ibadahnya, latihan secara sungguh-sungguh dan berusaha mengubahnya, serta mengadakan intropeksi diri. 
Dalam dunia tasawwuf diajarkan berbagai cara untuk itu, seperti riyādhah dan mujāhadah sebagai sarana untuk melawan hawa nafsu. Adapun cara pembinaannya melalui tiga tahapan, sebagai disebutkan Syukur (2002: 115), yakni tahap pembersihan dan pengosongan jiwa dari sifat-sifat tercela yang diistilahkan dengan takhalli, dan kedua, penghiasan diri dengan sifat-sifat terpuji (tahallī), dan ketiga, tercapainya sinar ilahi (tajalli) .

Pada saat perjuangan mengekang nafsu berlangsung, seseorang mengosongkan diri dari perbuatan buruk dan perilaku hati yang rendah (takhally), kemudian mengisi dirinya dengan perbuatan mulia (tahally). Pola takhliyah dan tahliyah inilah yang lazim dikenal dalam tasawwuf dalam rangka mujāhadatunnafs dan tazkiyatunnafs. Bila seseorang mendapati dirinya berperilaku kikir, maka jihad-nya adalah menekan sifat ini agar tidak mendominasi diri dan menimpanya dengan latihan-latihan (riyādhah) yang mendidikkan sifat dermawan, dan seterusnya. Inilah makna yang diajarkan oleh Rasulullah saat diminta memberi wejangan atau ditanya oleh para sahabat amal apa yang paling utama. Nabi saw. dalam berbagai riwayat menjawab dengan jawaban-jawaban yang tidak seragam. Nabi diketahui menjawab shalat pada waktunya, namun kepada orang lain Nabi menyatakan jangan marah, kepada yang lain berbakti kepada orangtua. Ini semua karena melihat pribadi penanya dan memprioritaskan kepada hal yang paling bermanfaat dan urgen bagi pribadinya.

\section{Jihad Intelektual}

Tuntutan yang muncul dari akibat modernisasi dan industrialisasi adalah pengembangan kemampuan intelektual muslim sehingga memiliki kemampuan dialogis dan fungsional terhadap perkembangan Iptek.

Secara epistimologis tasawwuf memakai metode intuitif, yang pada masa ini dapat dijadikan sebagai salah satu alternatif dari rasionalisme dan empirisme yang membantunya untuk melakukan terobosan baru dalam berbagai hal.

Intuisi merupakan salah satu tipe pengetahuan yang memiliki watak tinggi dari pada pengetahuan indera atau akal. Diakui bahwa arah intuisi itu berbeda, Jihad Sufi 
karena akal maupun indera merupakan instrumen yang lebih bekompoten untuk menghadapi obyek-obyek materi serta hubungan-hubungan kuantitatif.

Sementara itu, Bergson sebagai dikutip R. Paryana Suryadipura (1993: 123), intuisi sebagai naluri yang menjadi kesadaran diri manusia dapat menuntun pada kehidupan (immateri). Bahkan jika intuisi dapat meluas dan mendominasi manusia, ia dapat memberi petunjuk dalam hal-hal vital yang disebut elan vital.

Lebih lanjut disebutkan, pada diri manusia terdapat intuisi yang bersifat intraintelektual dan supraintelektual. Yang pertama adalah intuisi yang menyertai pikiran dan masuk pikiran manusia melalui indera. Yang kedua adalah intuisi yang tumbuh pada diri manusia tanpa didahului keterangan logis dan tidak bergantung pada pengamatan indera.

Jika keduanya dapat melakukan interaksi secara intens, akan memberi kemungkinan pada intuisi intraintelektual meningkat lebih tinggi lagi setelah terdominasi oleh intuisi supraintelektual. Bila sesorang telah didominasi intuisi supraintelektual maka kemauan dan dorongannya (elan vital)nya tidak terbatas pada persepsi bendawi yang nisbi, melainkan akan dapat meningkat pada serapanserapan pengetahuan yang bersifat mutlak (Suryadipura, 1993: 123).

Masalahnya ialah apa bukti yang dapat diterima. Pengetahuan intuitif memeiliki karakter yang berbeda dengan pengatahuan rasional yang dapat diukur kebenarannya dengan kualifikasi logis dan rasional, ataupun pengetahuan empirik (inderawi) yang dapat diukur dengan kualifikasi eksak dan kuantitatif.

David Truebood, sebagaimana dikutip Syukur, menjelaskan bahwa, paling tidak ada tiga hal yang harus dipenuhi agar kebenaran intuitif ini dapat diterima. Pertama, moralitas subyek atau penerima pengetahuan, sebab tidak setiap orang dapat mengikuti penyelidikannya secara kritis.

Kedua, akal sehat. Penilaian kevalidan pengetahuan intuitif sesorang dapat ditinjau dari sudut penalaran akal sehat, adakah fakta-fakta pengetahuan itu dapat dinalar (reasonable) atau tidak. Sebab pada akhirnya kita harus kembali pada akal, karena akal merupakan hakim terakhir. 
Ketiga, keahlian subyek secara tepat. Mengingat pengetahuan intuitif bukan seperti pengetahuan pada umumnya, maka untuk menilai kebenarannya harus melihat pada subyek penerimanya, adakah ia memiliki keahlian pada bidang itu. Lebih lanjut dikatakan bahwa, intuisi yang baik adalah intuisi orang-orang-orang yang sudah berpengalaman dan berkecimpung dalam bidang tertentu. Sebab fungsi metodologi maupun sistematika berpikir yang berupa logika tidak untuk memimpin pikiran agar bekerja setelah dihadapkan pada obyeknya, melainkan untuk mempertajam pikiran sebelum memulai penyelidikan (Syukur, 2002: 124).

Teori-teori ini sepertinya telah terbukti. Bukankah dalam sejarah ilmu pengetahuan Islam, telah banyak disaksikan ilmuan, filosof sufi yang brilian. AlFarabi misalnya, adalah seorang filosof, pemikir, yang telah banyak membaca dan menulis buku-buku dalam berbagai cabang ilmu pengetahuan, tetapi juga sebagai seorang sufi.

Kemudian kita kenal juga Ikhwān al-Shafāa, seperti ditulis Jalaluddin Rahmat, adalah kelompok gerakan sufi. Mereka berkumpul, berdiskusi, dan merekam pembicaraan mereka ke dalam 51 risalah yang sampai ke zaman ini. Dalam risalah itu, mereka bukan saja membicarakan masalah tauhid, akhlak, dan kesucian, tetapi juga mendiskusikan gelombang suara, gerhana, kimia, dan fenomena-fenomena alam lainnya. Mereka tidak hanya mengulas dialektika Sokrates, tetapi juga kezuhudan Alī bin Abi Thalib (Jalaluddin Rahmat, 1991: 216).

Dengan melihat kenyataan di atas, maka secara hipotesis bisa dikatakan bahwa semakin seseorang terbenam dalam pekerjaan penalaran dan keintelektualannya, maka dia juga akan semakin rindu dan butuh kepada kehangatan spiritualitas.

\section{Jihad Politik}

Jihad dalam syariat Islam mempunyai makna yang sangat luas, yaitu segala bentuk usaha maksimal untuk penerapan ajaran Islam dan pemberantasan kejahatan serta kezaliman, baik terhadap diri sendiri maupun selainnya. Ulama 
fikih membagi jihad menjadi tiga bentuk, yaitu: berjihad memerangi musuh secara nyata, berjihad melawan setan, dan berjihad terhadap diri sendiri.

Jihad dalam pengertian umum di atas mencakup juga seluruh jenis ibadah yang bersifat lahir dan batin, sebagaimana dicontohkan dalam sejarah perjuangan Nabi Muhammad saw. selama di Mekah dan Madinah. Di samping pengertian umum tersebut, ada juga pengertian khusus yang dikemukakan para ulama. Imam Syafi'i mendefinisikan jihad, yaitu memerangi kaum kafir untuk menegakkan Islam. Atau dengan mengorbankan harta dan jiwa untuk menegakkan Islam, mempertahankan wilayah/negara dan penindasan penguasa yang zalim. Pengertian jihad secara khusus inilah yang secara luas dibicarakan dalam kitabkitab fikih yang senantiasa dikaitkan dengan pertempuran, peperanngan, dan ekspedisi atau ekspansi militer (Dewan Redaksi Ensiklopedi Islam 2, 1994: 315).

Para sufi tidak hanya dituntut untuk berjihad dalam makna umum saja tetapi juga tidak boleh lepas dari jihad dalam makna khusus. Tasawwuf pada masa sekarang tidak lagi menjauhi kekuasaan, sebagaimana dilakukan oleh sebagian sufi klasik. Akan tetapi tanpil di tengah percaturan politik dan masuk dalam kekuasaan. Menjauhi kekuasaan, politik dan jihad menunjukkan kelemahan.

Tarekat Sanusiah dalam sejarah, menurut Stoddard, telah menjadi kekuatan besar dalam banyak perjuangan yang terjadi di Afrika Utara, telah berhasil memukul mundur penjajah Perancis dan mengusir Inggris dari Libia. Tarikat ini tak henti-hentinya bekerja dengan pendidikan kerohanian, disiplin tinggi, menggali sumur-sumur baru, dan memajukan perniagaan yang menarik orangorang ke dalam pahamnya (Stoddard, 1966: 56-57).

Fazlur Rahman menyatakan bahwa tarekat Sanusiah menanamkan disiplin tinggi dan aktif dalam medan perjuangan hidup, baik sosial, politik maupun ekonomi. Pengikutnya dilatih menggunakan senjata dan menjadi ekonom. Gerakannya berada pada perjuangan dan pembaharuan, dan programnya lebih berada dalam batasan positivisme moral dan kesejahteraan sosial daripada batasan-batasan spiritual keakhiratan, memberantas penyelewengan moral, sosial 
keagamaan. Fazlur Rahman menyebutkan tarekat Sanusiah sebagai neo-sufime (Rahman, 1979: 207-208).

Turki Usmani di masa jayanya, juga tidak terlepas dari para sufi dan tarekatnya. Tarekat yang paling berpengaruh ketika itu ialah tarekat Baktesyi. Tarekat ini merupakan tarekat yang didalami oleh para tentara militer. Para Sufi dengan ajaran tarekatnya sangat giat memberikan semangat kepada para penguasa dan tentaranya untuk berjihad menegakkan agama dan melebarkan sayap hingga hampir menguasai separuh benua Eropa.

Selanjutnya kita diingatkan dengan proses kemerdekaan Republik Indonesia. Aqib Suminto menyebutkan bahwa tarekat pernah dijadikan basis perjuangan melawan penjajah. Para pengikut tarekat pernah mengadakan pemberontakan di Cianjur (1885 M), peristiwa Cilegon Banten (1888 M), dan Peristiwa Garut (1919 M) (Syukur, 2002: 117).

Sebelumnya juga di nusantara ini, kita kenal Syekh Yusuf. Ia adalah seorang ulama, sufi dan pejuang abad ke-17 asal Kerajaan Gowa (Sulawesi Selatan). Syekh Yusuf yang telah mempelajari beberapa tarekat namun lebih terkenal dengan tarekat Khalwatiyahnya. Ketika hijrah ke Kerajaan Banten, beliau berjuang di sana bersama dengan Sultan Agung Tirtayasa melawan penjajah Belanda. Dan karena perlawanannya kepada Kolonial Belanda, Ia ditangkap dan diasingkan ke Ceylon, Srilangka. Tetapi karena pengaruhnya masih sangat besar, Kolonial Belanda kemudian pengasingannya dipindahkan ke Cafe Town, Afrika Selatan. Di Afrika Selatan juga masih tetap melanjutkan perjuangan. Di sana beliau berjuang mengangkat martabat manusia dengan berusaha memperjuangkan hak-hak asasi manusia, memperjuangkan persamaan dari ketidakadilan (Sultan, 2006: 29-39).

Ini membuktikan bahwa sufi, tasawwuf ataupun tarekat tidak menghalangi untuk berjihad baik itu dalam makna umum ataupun dalam makna khusus. Bahkan jika ajaran tasawwuf dan kesufian bisa menghiasi para penguasa dan elitelit politik, maka akan membuat pemerintahan akan semakin kokoh dan jauh dari 
penyelewengan-penyelewengan. Karenanya keberadaan tasawwuf dan tanggung jawabnya dalam kehidupan politik dan jihad di dunia ini sangat diharapkan dan dibutuhkan.

\section{SIMPULAN}

Tasawwuf merupakan salah satu bagian dari ajaran Islam, yang keilmuannya lahir di kemudian hari melalui proses yang panjang dengan dinamika dan perkembangannya sendiri. Secara esensial tasawwuf mempunyai ajaran sosial, namun selama ini sebagian masih bersifat passif dan kadang-kadang sebatas sikap kesalehan individual belum sampai pada tingkat kesalehan sosial. Ini merupakan akses dari pemahaman yang tidak kontekstual terhadap ajaran Tasawuf

Sufi dalam ber-tasawwuf seharusnya tidak hanya bersifat passif, namun dituntut untuk bersikat aktif dalam memecahkan semua problema kehidupan, seperti kehampaan spiritual, dekadensi moral, persolan politik, dan lainnya. Bahkan jihad dalam memperjuangkan agama dan negara dalam bentuk fisik, para sufi tidak boleh ketinggalan.

Tasawwuf bukan lagi menjadi tempat pelarian bagi sebagian orang, namum merupakan suatu keharusan yang sangat perlu diperhatikan oleh semua orang agar tidak menjadi momok dan penghalang dalam perbaikan dan perkembangan manusia itu sendiri sebagai subyek dan obyek.

\section{DAFTAR PUSTAKA}

Al-Qur'an al-Karim.

Dewan Redaksi Ensiklopedi Islam. 1994. Ensiklopedi Islam. Jld. 2. Cet. III; Jakarta: Ikhtiar Baru van Hoeve.

Dewan Redaksi Ensiklopedi Islam. 1994. Ensiklopedi Islam. Jld. 5. Cet. III; Jakarta: Ikhtiar Baru van Hoeve.

Hajāj, Muhammad Fauqī. 1992. Al-Tasawwuf al-Islāmī wa al-Akhlāq. Cet. I; Kairo: t.p. 
Hawari, Dadang. 1995. Al-Qur'an Ilmu Kedokteran dan Kesehatan Jiwa. Dana Bhakti Prima Yasa: Yogyakarta.

Mughni, Syafiq A. "Paradigma Tasawwuf dan Masa Depan Islam" Makalah Orasi Pengukuhan Guru Besar. http://kawulagusti.blogspot.com/2007/01/ paradigma-tasawwuf-masa-depan-islam.html (15 Januari 2010).

Nadvi, Muzaffaruddin. 1984. Muslim Thought and It's Source, terj. Adang Afandi, Pemikiran Muslim dan Sumber. Cet. I; Bandung: Pustaka.

Nasr, Sayyid Hosein. 1985. Tasawwuf Dulu dan Sekarang. Yogyakarta: Pustka Pelajar.

Nasution, Harun. 1978. Filsafat dan Mistisisme dalam Islam. Cet. II; Jakarta: Bulan Bintang.

Nasution, Harun. 1986. Islam Ditinjau dari Berbagai Aspeknya. Jld. II. Cet. VI; Jakarta: Bulan Bintang

Rahman, Fazlur. 1979. Islam. USA: The University of Chicago Press.

Rahmat, Jalaluddin. 1991. Islam Alternatif. Bandung: Mizan.

Shihab, M. Quraish. 1997. Wawasan al-Qur'an. Cet. VI; Bandung: Mizan.

Stoddard, Lothrop. 1966. The New World of Islam, terj. Dunia Baru Islam. Jakarta: T.p.

Sultan, Sahib. 2006.s Allah dan Jalan Mendekatkan Diri Kepadanya dalam Konsepsi Syekh Yusuf, Cet. 3; Makassar: Yapma Makassar.

Suryadipura, R. Paryana. 1993. Alam Pikiran. Jakarta: Bumi Aksara.

Syukur, H.M. Amin. 2002. Menggugat Tasawuf Cet. II; Yogyakarta: Pustaka Pelajar.

Syukur, H.M. Amin. 1997. Zuhud di Abad Moderen. Yogyakarta: Pustaka Pelajar. 